\title{
Assessment of learning needs and the development of an educational programme for registered nurses in advanced midwifery and neonatology
}

\author{
AE Fichardt, Ph.D., School of Nursing, UOFS \\ MJ Viljoen, D.Soc.Sc., School of Nursing, UOFS
}

\section{Abstract}

A key step in the development of any educational programme is learning needs assessment. This is however often neglected. The purpose of this research was to identify learning needs of potential students in order to develop a relevant educational programme for registered nurses in advanced midwifery and neonatology. A survey design was used, and the population of the study was the registered nurses in the Free State. Two thousand questionnaires were mailed to respondents, selected by means of simple random sampling. Advanced educational programmes emphasize the teaching of advanced knowledge and skills and accept that the students entering these programmes already have specific knowledge and skills included in the curricula for basic programmes. This is contrary to the findings of this study. The results underline the importance of learning needs assessment in the development of relevant educational programmes.

\section{Opsomming}

' $n$ Belangrike stap in die ontwikkeling van enige opvoedkundige program is die bepaling van leerbehoeftes. Dit word egter dikwels afgeskeep. Die doel van die studie was om die leerbehoeftes van potensiële studente te bepaal om sodoende ' $\mathrm{n}$ toepaslike opvoedkundige program vir geregistreerde verpleegkundiges in gevorderde verloskunde en neonatologie te ontwikkel. "n Opname ontwerp is gebruik, en die populasie van die studie was die geregistreerde verpleegkundiges in die Vrystaat. Twee duisend vraelyste is aan geregistreerde verpleegkundiges in die Vrystaat, wat op ' $n$ eenvoudige ewekansige wyse geselekteer is, gestuur. Gevorderde opvoedkundige programme beklemtoon die onderrig van gevorderde kennis en vaardighede en aanvaar dat die studente wat vir hierdie programme inskryf, reeds oor spesifieke, basiese kennis en vaardighede beskik. Dit is in teenstelling met die bevindinge van die studie. Die resultate beklemtoon die belangrikheid van ' $n$ leerbehoefte bepaling in die ontwikkeling van relevante opvoedkundige programme.

\section{Introduction and problem statement}

In the development of educational programmes, much attention is paid to the method of delivery. Just as important, but relatively neglected is the question of learning needs assessment. Without any form of learning needs assessment, education becomes teacher-oriented and directed. Learning needs assessment is important to obtain information to determine the nature, extent and priority of educational needs to develop courses (Matiru, Mwangi \& Schlette, 1995:43). It involves identifying the gaps between current knowledge and skills and desired practice. Remedying these deficiencies is the aim of an educational programme. Only if these gaps are recognized is it possible to be confident that the aims and design of the educational programme are appropriate (Laidlaw, Harden and Morris 1995:80).

Murray (1982:18) supports these statements and adds that the teacher's primary function is to diagnose learning needs and problems and together with the student plan strategies

that will result in success for the learner. When one is learning what one wants to learn, and can use any resources available and any method that one chooses, learning and growing are life.

Academic staff commonly overestimate skills, prior knowledge and competencies of students. They assume that students have the prerequisites that courses require. This gap between what is expected and what actually exists is significant and is sometimes the cause of failure of students. In this regard Diamond (1989:47) refers to other studies and states that insensitivity to students' backgrounds, interests and needs is a primary reason that many students feel dissatisfied with or leave their institutions.

However, needs assessment is not the responsibility only of the teachers. As many universities move towards open and self-learning programmes it becomes increasingly important for students to undertake needs assessments themselves.

Matiru et al. (1995:43) refer to an educational need as a discrepancy between an existing set of circumstances and some 


\begin{tabular}{|c|c|c|c|}
\hline \multicolumn{4}{|c|}{ QUESTIONNAIRE } \\
\hline Checklist A & Question & Checklist B & Question \\
\hline \begin{tabular}{ll}
\multicolumn{2}{l}{ Profile data } \\
- & Sociographic \\
- & Educational \\
- & Vocational \\
- & Opinion on services rendered \\
- & Professional development \\
- & Need for an advanced diploma in \\
& midwifery and neonatology
\end{tabular} & $\begin{array}{c}1-2 \\
3-7 \\
8-15 \\
16,17 \\
18-23,28 \\
24-27\end{array}$ & \begin{tabular}{ll}
\multicolumn{2}{l}{ Self-perceived competency data } \\
- & General Nursing Care \\
- & Antenatal Nursing Care \\
- & Intrapartum Nursing Care \\
- & Postnatal Nursing Care \\
- & Neonatal Nursing Care
\end{tabular} & $\begin{array}{c}1,2 \\
3 \\
4,5 \\
6,7 \\
8,9\end{array}$ \\
\hline
\end{tabular}

desired set of circumstances. These discrepancies can be described in terms of knowledge, attitude, performance or setting.

\section{Aim of the study}

The aim of the research was to determine the learning needs of potential students in order to develop a relevant educational programme for registered nurses in advanced midwifery and neonatology.

\section{Research methodology and sampling}

The aim of the research was descriptive and developmental.

The target population was identified as all the registered nurses in the geographical area of the Free State. With the help of a professional organisation the total population of registered nurses and midwives in the Free State was established at 5 996.

Simple random sampling was done by means of a computer programme. A sample size of $2000(40 \%)$ was used. This large sample was considered as a relevant approximation of the target population and the possibility of achieving statistical significance was greater. (Burns \& Grove, 1997:308).

Although strategies to increase the response rate, such as enclosing a stamped, addressed envelope and mailing a reminder were implemented, the response rate was $26,2 \%$

\section{Research technique}

A questionnaire similar to the one mentioned by Diamond (1989:59) was developed to obtain the data on the learning needs of registered nurses regarding midwifery and perinatology. Questionnaires are extremely effective tools for collecting discipline - specific information (Diamond, 1989:59). The questionnaire was thus considered appropriate as a data collection technique. It was cost-effective in the sense of money and time and the data which were collected, did not require in-depth interviewing. Questions were presented in a consistent manner, and there was less opportunity for bias than by interviews (Burns \& Grove, 1997:358).

The questionnaire was divided in to two parts (Checklist A and Checklist B). Table 1 indicates the topics covered in the questionnaire. In checklist A the possible responses were provided, but an open category was left, where appropriate, for answers other than those provided. Three open questions were included in this part of the questionnaire.

In Checklist B respondents were requested to rate their clinical competency as perceived on a five point Likert-type scale (Table 1).

The data was collected over a four month period, and a total of 523 questionnaires were returned; a response rate of $26,2 \%$. Nine questionnaires $(0,45 \%)$ were returned as undelivered, thus $514(25,7 \%)$ questionnaires were analyzed.

\section{Validity and reliability}

The following steps were implemented to measure up to the demands of validity:

- The scope of practice of the midwife was studied, and the essential content dimensions (student profile and competency) to be covered by the questionnaire were identified. Items were formulated according to the dimensions, and a decision was made on how many items were to be included under each dimension in order to collect the information required. (Skills, for example assisted deliveries, not included in undergraduate courses but expected from nurses working in specific health care centres were included.)

- For the sake of clarity the questionnaire was translated into English and Afrikaans. A linguist evaluated the questionnaires in both languages.

- Open and closed ended questions were used to obtain a variety of data.

- The questionnaires were submitted to six domain experts to be judged. They evaluated whether the items were representative of the dimensions identified, the sequence of the items and the face validity of the instrument. Several items were modified in accordance with suggestions from the experts.

- A pilot test of the questionnaires was performed. Ten registered nurses with midwifery registrations and expertise were used for the test. Respondents of the pilot study were asked to judge the questionnaire for ambiguity, clarity and the time required to complete the questionnaire. The phraseology and/ 
TABLE 2: Self-perceived competency: General

\begin{tabular}{|c|c|c|c|c|c|c|c|c|c|c|}
\hline \multirow[t]{2}{*}{ NURSING KNOWLEDGE AND SKILLS } & \multicolumn{2}{|c|}{ Poor } & \multicolumn{2}{|c|}{ Reasonable } & \multicolumn{2}{|c|}{ Good } & \multicolumn{2}{|c|}{ Very Good } & \multicolumn{2}{|c|}{ Excellent } \\
\hline & $\mathbf{f}$ & $\%$ & f & $\%$ & f & $\%$ & $\mathbf{f}$ & $\%$ & $\mathbf{f}$ & $\%$ \\
\hline Urinary catheterisation & 20 & 3.9 & 56 & 10.9 & 159 & 30.9 & 148 & 28.8 & 131 & 25.5 \\
\hline Vulva swabbing & 21 & 4.1 & 55 & 10.7 & 177 & 34.4 & 137 & 26.7 & 124 & 24.1 \\
\hline Commencing an intravenous line & 57 & 11.1 & 67 & 13.0 & 149 & 29 & 128 & 24.9 & 113 & 22.0 \\
\hline Setting up an infusion pump (IVAC) & 123 & 23.9 & 87 & 16.9 & 107 & 20.8 & 96 & 18.7 & 101 & 19.6 \\
\hline Adult resuscitation & 73 & 14.2 & 131 & 25.5 & 169 & 32.9 & 90 & 17.5 & 51 & 9.9 \\
\hline Administering blood transfusions & 51 & 9.9 & 62 & 12.1 & 167 & 32.5 & 122 & 23.7 & 112 & 21.8 \\
\hline $\begin{array}{l}\text { Preparing a patient for obstetric diagnostic proce- } \\
\text { dures }\end{array}$ & 93 & 18.1 & 92 & 17.9 & 149 & 29.0 & 106 & 20.6 & 74 & 14.4 \\
\hline Performing endotracheal intubation & 290 & 56.4 & 104 & 20.2 & 68 & 13.2 & 36 & 7 & 16 & 3.1 \\
\hline Administering intravenous infusions & 37 & 7.2 & 32 & 6.2 & 145 & 28.2 & 158 & 30.7 & 142 & 27.6 \\
\hline $\begin{array}{l}\text { Administering oxygen (in different percentage e.g. } \\
40 \% \text { ) }\end{array}$ & 22 & 4.3 & 58 & 11.3 & 141 & 27.4 & 139 & 27.0 & 154 & 30.0 \\
\hline Wound care & 12 & 2.3 & 37 & 7.2 & 186 & 36.2 & 174 & 33.9 & 105 & 20.4 \\
\hline Obtaining blood samples & 14 & 2.7 & 29 & 5.6 & 122 & 23.7 & 172 & 33.5 & 177 & 34.4 \\
\hline \multicolumn{11}{|l|}{ Taking a history } \\
\hline Physical assessment: & 12 & 2.3 & 25 & 4.9 & 147 & 28.6 & 184 & 35.8 & 146 & 28.4 \\
\hline assessing hydration status & 36 & 7.0 & 71 & 13.8 & 177 & 34.4 & 145 & 28.2 & 85 & 16.5 \\
\hline general & 24 & 4.7 & 54 & 10.5 & 207 & 40.3 & 137 & 26.7 & 92 & 17.9 \\
\hline - $\quad$ speculum examination & 140 & 27.2 & 127 & 24.7 & 141 & 27.4 & 71 & 13.8 & 35 & 6.8 \\
\hline vaginal examination & 95 & 18.5 & 116 & 22.6 & 157 & 30.5 & 87 & 16.9 & 59 & 11.5 \\
\hline Identifying physical needs & 20 & 3.9 & 79 & 15.4 & 226 & 44.0 & 135 & 26.3 & 54 & 10.5 \\
\hline Identifying psychological needs & 31 & 6.0 & 91 & 17.7 & 231 & 44.9 & 119 & 23.2 & 42 & 8.2 \\
\hline Identifying educational needs & 33 & 6.4 & 90 & 17.5 & 210 & 40.9 & 134 & 26.1 & 47 & 9.1 \\
\hline Formulating a nursing diagnosis & 37 & 7.2 & 100 & 19.5 & 209 & 40.7 & 126 & 24.6 & 41 & 8.0 \\
\hline $\begin{array}{l}\text { Establishing a therapeutic relationship with: } \\
\text { - patients }\end{array}$ & 19 & 3.7 & 55 & 10.7 & 189 & 36.8 & 167 & 35 & 84 & 16.3 \\
\hline family & 19 & 3.7 & 70 & 13.6 & 193 & 37.5 & 160 & 31.1 & 72 & 14.0 \\
\hline nursing staff & 18 & 3.5 & 55 & 10.7 & 197 & 38.3 & 170 & 33.1 & 74 & 14.4 \\
\hline $\begin{array}{l}\text { Co-ordinating health care regimes provided for the } \\
\text { patient by other categories of health personnel }\end{array}$ & 112 & 21.8 & 101 & 19.6 & 180 & 35.0 & 97 & 18.9 & 24 & 4.7 \\
\hline Formulating a community diagnosis & 75 & 14.6 & 146 & 28.4 & 175 & 34.0 & 99 & 19.3 & 19 & 3.7 \\
\hline Prioritizing health risks & 61 & 11.9 & 114 & 22.2 & 201 & 39.1 & 107 & 20.8 & 31 & 6.0 \\
\hline $\begin{array}{l}\text { Interpreting vital statistics of populations: } \\
\text { - } \quad \text { growth rate } \\
\end{array}$ & 138 & 26.8 & 166 & 32.3 & 136 & 26.5 & 55 & 10.7 & 19 & 3.7 \\
\hline - $\quad$ birth rate & 128 & 24.9 & 158 & 30.7 & 145 & 28.2 & 61 & 11.9 & 22 & 4.3 \\
\hline maternal and child mortality (death rates) & 129 & 25.1 & 153 & 29.8 & 141 & 27.4 & 68 & 13.2 & 23 & 4.5 \\
\hline fertility rate & 151 & 29.4 & 167 & 32.5 & 134 & 26.1 & 48 & 9.3 & 14 & 2.7 \\
\hline Planning preventive health programmes & 78 & 15.2 & 150 & 29.2 & 162 & 31.5 & 81 & 15.8 & 43 & 8.4 \\
\hline Training community health workers & 118 & 20.3 & 124 & 24.1 & 147 & 28.6 & 91 & 17.7 & 34 & 6.6 \\
\hline Conducting research & 189 & 36.8 & 150 & 29.2 & 122 & 23.7 & 43 & 8.4 & 10 & 1.9 \\
\hline Writing a research report & 208 & 40.5 & 166 & 32.3 & 99 & 19.3 & 31 & 6.0 & 10 & 1.9 \\
\hline Interpreting research findings & 182 & 35.4 & 169 & 32.9 & 120 & 23.3 & 33 & 6.4 & 10 & 1.9 \\
\hline Educating the community & 58 & 11.3 & 110 & 21.4 & 185 & 36.0 & 101 & 19.6 & 60 & 11.7 \\
\hline
\end{tabular}


or construction of a few questions were modified after the pilot study.

- Because of the sensitive nature of the questionnaire - respondents were asked to evaluate their own knowledge and skills - anonymity was ensured.

The reliability of the questionnaire was ensured by asking five respondents of the pilot study to complete a questionnaire two weeks after completion of the first one. The researcher checked both questionnaires of the five respondents for variation on specific questions and items which were unanswered. In this way ambiguous and unclear questions could be identified and modified. The responses to both questionnaires were nearly identical and the minimum number of questions were left unanswered. It was accepted that reliability was proven.

\section{Data-analysis}

Descriptive and inferential statistics were used in the dataanalysis. The Statistical Analysis System was used for the analysis. The chi-square non-parametric statistical and Fisher's exact tests were used to determine correlation.

\section{Results Profile data}

\section{- Sociographic background}

The age distribution demonstrates that the age group 40-49 was the largest group of respondents. The second largest group was 30-39. This implies a potentially older student population. There were significantly more female $(96 \%)$ than male (4\%) respondents.

\section{- Educational background}

Eighty-nine percent of the respondents were in possession of a Standard 10 certificate. A diploma in nursing was the highest level of education for $77,3 \%$ of the respondents. Only $3,9 \%$ of the respondents had a higher qualification than a baccalaureate degree. This implies the existence of a large potential post-basic nursing student population in the Free State.

An analysis of the professional registrations in nursing indicates that $99,2 \%$ of the respondents had a professional qualification in general nursing, $94,2 \%$ had a midwifery qualification, $38,7 \%$ had a professional qualification in psychiatric nursing and $53,1 \%$ had a professional qualification in community nursing. Only $1,2 \%$ of the respondents had a professional qualification in advanced midwifery and neonatology. A high percentage of the respondents $(93,6 \%)$ had the two qualifications, general nursing and midwifery. Most of the respondents $(80,6 \%)$ completed their basic training more than 10 years ago.

\section{- Vocational background}

The majority of the respondents $(51,5 \%)$ were working in hospitals and $27,9 \%$ worked in community settings. The analysis indicated that $42,9 \%$ of the respondents had worked in their current position for $0-5$ years, while $30,1 \%$ had been employed in the specific capacity between 11 and 35 years. Cumulatively $73,6 \%$ of the respondents have a productive live of 11 years or more before retirement.

It was indicated that $71,2 \%$ of the respondents had practised midwifery during their professional career, while $28,8 \%$ respondents never had. The majority of the respondents had not practised midwifery for the past five years, $31,9 \%$ were practising midwifery at the time of the study, while $19,1 \%$ had done 50 for the past 1-4 years.

\section{- Opinion on services rendered}

The majority of the respondents were of the opinion that the newborn and mother in all stages of labour receive optimum care. Cumulatively $21,1 \%$ of the respondents did not think or were unsure if optimum patient care was delivered to the newborn. Twenty-three percent of the respondents had the same opinion about antenatal care, while $20,9 \%$ and $22,7 \%$ indicated these opinions on intrapartum and postpartum care respectively.

\section{- Professional development}

The analysis of the educational opportunities the respondents would be interested in attending indicated that $60,1 \%$ of the respondents identified courses as the most likely followed by seminars $(58,8 \%)$, in service training $(57 \%)$ and workshops $(47,3 \%)$. An interest in an advanced diploma in midwifery and neonatology exists as $36,3 \%$ of the respondents stated their interest. It is important to develop an educational programme appropriate for its users. Most of the respondents $(43,3 \%)$ perceived the need for a distance learning programme, with self-directed learning packages and contact sessions. A full time residential course was preferred by $32,5 \%$ of the respondents.

\section{Self perceived knowledge data}

\section{- South African Nursing Council regulations}

It is alarming that although $94,3 \%$ of the respondents indicated that they were currently practising as nurses, less than a quarter of the respondents scored their knowledge of the regulations of the South African Nursing Council as very good or excellent. Only $20,8 \%$ of the respondents evaluated their knowledge on the scope of practice (R.260 of 1991) as very good or excellent, while $21,4 \%$ evaluated their knowledge on the regulation regarding acts and omissions (R.2490 of 1990) on the same level. A hundred and fourteen $(22,2 \%)$ and $22,6 \%$ of the respondents respectively indicated that their knowledge of medications which midwives may prescribe (R.2418 of 1984) and conditions under which midwives may carry on their profession (R.2488 of 1990) was very good or excellent.

\section{- Cultural, traditional and customary beliefs and practices of patients}

The respondents were also requested to score their knowledge on cultural, traditional and customary beliefs and practices of patients. Until recently these aspects were not emphasized in the curricula. It is therefore not surprising that only a small percentage $(13,6 \%, 14,2 \%$ and $14,6 \%)$ of the respondents' knowledge in these categories was very good or excellent. 


\begin{tabular}{|c|c|c|c|c|c|c|c|c|c|c|}
\hline \multirow[t]{2}{*}{ ANTENATAL NURSING CARE } & \multicolumn{2}{|c|}{ Poor } & \multicolumn{2}{|c|}{ Reasonable } & \multicolumn{2}{|c|}{ Good } & \multicolumn{2}{|c|}{ Very Good } & \multicolumn{2}{|c|}{ Excellent } \\
\hline & f & $\%$ & $\mathbf{f}$ & $\%$ & $\mathbf{f}$ & $\%$ & f & $\%$ & f & $\%$ \\
\hline $\begin{array}{l}\text { Planning a diet to meet specific health care needs in } \\
\text { pregnancy }\end{array}$ & 85 & 16.5 & 158 & 30.7 & 164 & 31.9 & 70 & 13.6 & 37 & 7.2 \\
\hline $\begin{array}{l}\text { Assessing foetal well-being and uterine activity: } \\
\text { - interpret and analyse cardiotocograph results/find- } \\
\text { ings }\end{array}$ & 282 & 54.9 & 120 & 23.3 & 60 & 11.7 & 36 & 7.0 & 16 & 3.1 \\
\hline - do a non-stress test & 329 & 64.0 & 98 & 19.1 & 52 & 10.1 & 22 & 4.3 & 13 & 2.5 \\
\hline - do an oxytocin stress test & 335 & 65.2 & 97 & 18.9 & 49 & 9.5 & 20 & 3.9 & 13 & 2.5 \\
\hline Assisting with an amniocentesis & 266 & 51.8 & 109 & 21.2 & 90 & 17.5 & 30 & 5.8 & 19 & 3.7 \\
\hline $\begin{array}{l}\text { Interpreting the results of examinations/ investiga- } \\
\text { tions }\end{array}$ & 191 & 37.2 & 140 & 27.2 & 110 & 21.4 & 52 & 10.1 & 21 & 4.1 \\
\hline Recognising dysrhythmias (ECG) & 174 & 33.9 & 158 & 30.7 & 105 & 20.4 & 57 & 11.1 & 20 & 3.9 \\
\hline Making neurological observations & 95 & 18.5 & 131 & 25.5 & 158 & 30.7 & 95 & 18.5 & 35 & 6.8 \\
\hline Identifying anaphylaxis & 71 & 13.8 & 169 & 32.9 & 177 & 34.4 & 69 & 13.4 & 28 & 5.4 \\
\hline Abdominal palpation & 57 & 11.1 & 101 & 19.6 & 182 & 35.4 & 112 & 21.8 & 62 & 12.1 \\
\hline Pelvic assessment & 187 & 36.4 & 134 & 26.1 & 113 & 22.0 & 51 & 9.9 & 29 & 5.6 \\
\hline $\begin{array}{l}\text { The pregnant woman with: } \\
\text { - a heart disease }\end{array}$ & 71 & 13.8 & 169 & 32.9 & 177 & 34.4 & 69 & 13.4 & 28 & 5.4 \\
\hline - $\quad$ diabetes mellitus & 58 & 11.3 & 162 & 31.5 & 176 & 34.2 & 87 & 16.9 & 31 & 6.0 \\
\hline - $\quad$ anaemia & 57 & 11.1 & 144 & 28.0 & 193 & 37.5 & 91 & 17.7 & 29 & 5.6 \\
\hline - hypertension & 46 & 8.9 & 130 & 25.3 & 196 & 38.1 & 105 & 20.4 & 37 & 7.2 \\
\hline - $\quad$ placenta praevia & 84 & 16.3 & 150 & 29.2 & 181 & 35.2 & 71 & 13.8 & 28 & 5.4 \\
\hline - $\quad$ trauma due to an accident & 105 & 20.4 & 150 & 29.2 & 176 & 34.2 & 63 & 12.3 & 20 & 3.9 \\
\hline - $\quad$ a sexually transmitted infection & 68 & 13.2 & 121 & 23.5 & 192 & 37.4 & 94 & 18.3 & 39 & 7.6 \\
\hline The battered pregnant woman & 110 & 21.4 & 159 & 30.9 & 159 & 30.9 & 66 & 12.8 & 20 & 3.9 \\
\hline The pregnant woman practising substance abuse & 123 & 23.9 & 174 & 33.9 & 135 & 26.3 & 64 & 12.5 & 18 & 3.5 \\
\hline
\end{tabular}

\section{Self-perceived competency data}

\section{- Self-perceived competency: General nursing}

The self-perceived competency of the respondents related to general nursing is set out in Table 2 .

It is a course for concern that only $27,4 \%$ of the respondents rated themselves very good or excellent at adult resuscitation - a life saving skill and 10,1\% rated themselves very good or excellent at endotracheal intubation.

Only $20,6 \%$ and $28,4 \%$ of the respondents respectively rated their knowledge and skills at speculum and vaginal examination as very good or excellent. It is interesting to note that while $44,6 \%$ of the respondents indicated that they were very good or excellent at doing a general physical assessment, only $36,8 \%$ evaluated their skill at identifying physical needs on the same level. A very good or excellent competency in identifying psychological and educational needs was indicated by $31,3 \%$ and $35,2 \%$ respectively of the respondents.

A hundred and sixty-seven of the respondents $(32,6 \%)$ indi- cated that they were very good or excellent at formulating a nursing diagnosis. Only $23,5 \%$ rated their competency as being very good or excellent at co-ordinating health care regimes provided for the patient by other categories of health personnel. It is alarming that only $23 \%$ and $26,8 \%$ of the respondents respectively indicated that they were very good or excellent at formulating a community diagnosis or prioritizing health risks.

The interpretation of vital statistics of the population seems to be a problem. One hundred and thirty-eight of the respondents $(26,8 \%)$ indicated their competency at interpreting growth rates as being poor with $24,9 \%$ and $25,1 \%$ of the respondents respectively evaluating their skills at interpreting birth and maternal and child mortality rates on the same level. A hundred and fifty-one of the respondents $29,4 \%$ indicated that their skills in interpreting fertility rates were poor.

\section{- Self-perceived competency: Antenatal related nursing care}

Respondents were asked to evaluate their competency in nurs- 
TABLE 4: Self-perceived competency: Intrapartum related nursing care

\begin{tabular}{|c|c|c|c|c|c|c|c|c|c|c|}
\hline \multirow[t]{2}{*}{ INTRAPARTUM NURSING CARE } & \multicolumn{2}{|c|}{ Poor } & \multicolumn{2}{|c|}{ Reasonable } & \multicolumn{2}{|c|}{ Good } & \multicolumn{2}{|c|}{ Very Good } & \multicolumn{2}{|c|}{ Excellent } \\
\hline & $\mathbf{f}$ & $\%$ & $\mathbf{f}$ & $\%$ & f & $\%$ & $\mathbf{f}$ & $\%$ & $\mathbf{f}$ & $\%$ \\
\hline $\begin{array}{l}\text { Monitoring a patient on: } \\
\text { - } \quad \text { Ipradol } ® \\
\end{array}$ & 177 & 34.4 & 115 & 22.4 & 126 & 24.5 & 55 & 10.7 & 41 & 80.0 \\
\hline Magnesium sulphate® & 213 & 41.4 & 117 & 22.8 & 104 & 20.2 & 51 & 9.9 & 29 & 5.6 \\
\hline Syntocinon ${ }^{\circledR}$ & 153 & 29.8 & 128 & 24.9 & 125 & 24.3 & 61 & 11.9 & 47 & 9.1 \\
\hline Setting up a cardiotocograph monitor & 287 & 55.8 & 93 & 18.1 & 68 & 13.2 & 41 & 8.0 & 25 & 4.9 \\
\hline Analysing and interpreting cardiotocograph findings & 306 & 59.5 & 90 & 17.5 & 67 & 13.0 & 28 & 5.4 & 23 & 4.5 \\
\hline Artificial rupturing of membranes & 166 & 32.3 & 114 & 22.2 & 126 & 24.5 & 62 & 12.1 & 46 & 8.9 \\
\hline Performing an episiotomy & 134 & 26.1 & 125 & 24.3 & 179 & 34.8 & 47 & 9.1 & 29 & 5.6 \\
\hline Doing a vaginal delivery & 93 & 18.1 & 116 & 22.6 & 199 & 38.7 & 70 & 13.6 & 36 & 7.0 \\
\hline Detecting threatened uterine rupture & 209 & 40.7 & 139 & 27.0 & 117 & 22.8 & 38 & 7.4 & 11 & 2.1 \\
\hline $\begin{array}{l}\text { Assisting anaesthetist: } \\
\text { - during administration of an epidural anaesthetic }\end{array}$ & 235 & 45.7 & 106 & 20.6 & 93 & 18.1 & 57 & 11.1 & 23 & 4.5 \\
\hline Giving epidural topping up & 296 & 57.6 & 105 & 20.4 & 68 & 13.2 & 35 & 6.8 & 10 & 1.9 \\
\hline Recognising spinal shock & 287 & 55.8 & 107 & 20.8 & 78 & 15.2 & 32 & 6.2 & 10 & 1.9 \\
\hline Treating hypoglycemia & 146 & 28.4 & 130 & 25.3 & 142 & 27.6 & 73 & 14.2 & 23 & 4.5 \\
\hline Treating hypotension & 122 & 23.7 & 137 & 26.7 & 143 & 27.8 & 84 & 16.3 & 28 & 5.4 \\
\hline Treating uterine hyperactivity & 249 & 48.4 & 120 & 23.3 & 86 & 16.7 & 47 & 9.1 & 12 & 2.3 \\
\hline Treating foetal distress & 165 & 32.1 & 129 & 25.1 & 121 & 23.5 & 68 & 13.2 & 31 & 6.0 \\
\hline Diagnosing abruptio placentae & 191 & 37.2 & 125 & 24.3 & 110 & 21.4 & 64 & 12.5 & 24 & 4.7 \\
\hline Administering entonox & 337 & 65.6 & 99 & 19.3 & 51 & 9.9 & 21 & 4.1 & 6 & 1.2 \\
\hline Applying a foetal scalp electrode & 382 & 74.3 & 69 & 13.4 & 38 & 7.4 & 13 & 2.5 & 12 & 2.5 \\
\hline $\begin{array}{l}\text { Assisted delivery: } \\
\text { - forceps delivery }\end{array}$ & 342 & 66.5 & 80 & 15.6 & 61 & 11.9 & 18 & 3.5 & 13 & 2.5 \\
\hline - $\quad$ vacuum extraction delivery & 338 & 65.8 & 76 & 14.8 & 65 & 12.6 & 22 & 4.3 & 13 & 2.5 \\
\hline - $\quad$ breech delivery & 277 & 53.9 & 106 & 20.6 & 80 & 15.6 & 31 & 6.0 & 20 & 3.9 \\
\hline - $\quad$ symphysiotomy & 397 & 77.2 & 70 & 14.0 & 36 & 7.0 & 4 & 0.8 & 5 & 1.0 \\
\hline Manual removal of placenta & 297 & 57.8 & 109 & 21.2 & 66 & 12.8 & 29 & 5.6 & 13 & 2.5 \\
\hline Examining the placenta & 103 & 20.0 & 100 & 19.5 & 153 & 29.8 & 114 & 22.2 & 44 & 8.6 \\
\hline Repairing perineal tears & 188 & 36.6 & 103 & 20.0 & 122 & 23.7 & 63 & 12.3 & 38 & 7.4 \\
\hline Scrubbing for caesarean sections & 246 & 47.9 & 84 & 16.3 & 91 & 17.7 & 52 & 10.1 & 41 & 8.0 \\
\hline $\begin{array}{l}\text { Patient education } \\
\text { - } \quad \text { Alternative methods of pain control }\end{array}$ & 128 & 24.9 & 148 & 28.8 & 152 & 29.6 & 56 & 10.9 & 30 & 5.8 \\
\hline Alternative positioning during labour & 147 & 28.6 & 149 & 2.9 & 148 & 28.8 & 40 & 7.8 & 30 & 5.8 \\
\hline Bonding & 93 & 18.1 & 91 & 17.7 & 174 & 33.9 & 96 & 18.7 & 60 & 11.7 \\
\hline Breastfeeding & 48 & 9.3 & 56 & 10.9 & 172 & 33.5 & 138 & 26.8 & 100 & 19.5 \\
\hline
\end{tabular}

ing actions related to the health care of pregnant women in the antenatal period. These responses are set out in Table 3.

The competency of the respondents on the assessment of foetal well-being is distressing. Two hundred and eighty-two of the respondents $(54,9 \%)$ indicated that they were poor at interpreting and analyzing the foetal heart pattern. Even more, $64 \%$ of the respondents evaluated their competency at doing a non-stress test as poor, while $65,2 \%$ indicated that their knowledge and skills of an oxytocin stress test was poor.

Two hundred and sixty-six of the respondents $(51,8 \%)$ indicated that their knowledge and skills at assisting with an amniocentesis was poor. Competency at interpreting the results of examinations/investigations performed in the antenatal period was perceived by $37,2 \%$ of the respondents as 
TABLE 5: Self-perceived competency: Postnatal nursing care

\begin{tabular}{|l|c|c|c|c|c|c|c|c|c|c|}
\hline \multirow{2}{*}{ POSTNATAL NURSING CARE } & \multicolumn{2}{|c|}{ Poor } & \multicolumn{2}{c|}{ Reasonable } & \multicolumn{2}{c|}{ Good } & \multicolumn{2}{c|}{ Very Good } & \multicolumn{2}{c|}{ Excellent } \\
\cline { 2 - 13 } & $\mathbf{f}$ & $\%$ & $\mathbf{f}$ & $\%$ & $\mathbf{f}$ & $\%$ & $\mathbf{f}$ & $\%$ & $\mathbf{f}$ & $\%$ \\
\hline Identifying involution of uterus and perineum & 149 & 29.0 & 99 & 19.3 & 147 & 28.6 & 79 & 15.4 & 40 & 7.8 \\
\hline Assessing hydration status & 55 & 10.7 & 71 & 13.8 & 183 & 35.6 & 124 & 24.1 & 81 & 15.8 \\
\hline Facilitating breastfeeding practices & 83 & 16.1 & 101 & 19.6 & 159 & 30.9 & 114 & 22.2 & 57 & 11.1 \\
\hline Operating the breast pump & 25 & 4.9 & 40 & 7.8 & 158 & 30.7 & 177 & 34.4 & 114 & 22.2 \\
\hline Teaching general hygiene & 33 & 6.4 & 52 & 10.1 & 170 & 33.1 & 170 & 33.1 & 89 & 17.3 \\
\hline Providing comfort measures (emotional and physical) & 125 & 243 & 95 & 18.5 & 113 & 26.7 & 113 & 22.0 & 44 & 8.6 \\
\hline Nursing a patient who has had an epidural anaesthetic & 27 & 5.3 & 77 & 15.0 & 174 & 33.3 & 174 & 33.9 & 65 & 12.6 \\
\hline Identifying patients at risk of postpartum depression & 52 & 10.1 & 104 & 20.2 & 130 & 35.8 & 130 & 25.3 & 44 & 8.6 \\
\hline Identifying and treating postpartum haemorrhage & 79 & 15.4 & 100 & 19.5 & 120 & 33.7 & 120 & 23.3 & 42 & 8.2 \\
\hline Identifying and treating infection of the genital tract & 82 & 16.0 & 99 & 19.3 & 113 & 35.2 & 113 & 22.0 & 39 & 7.6 \\
\hline Identifying and treating thrombosis & 79 & 15.4 & 145 & 28.2 & 97 & 33.3 & 97 & 18.9 & 22 & 4.3 \\
\hline
\end{tabular}

poor.

It is significant that respondents rated their competency (very good and excellent) much higher in nursing actions, such as recognising dysrhythmias (ECG) (15\%); making neurological observations $(25,3 \%)$ and identifying anaphylaxis $(18,8 \%)$ that are not exclusively related to perinatal health care.

It is encouraging to note that $33,9 \%$ respondents rated their competency at abdominal palpation at the very good or excellent level, although only $15,6 \%$ of the respondents rated their competency in doing a pelvic assessment as very good or excellent.

One hundred-and-five respondents $(20,4 \%)$ indicated that their knowledge and skills regarding the antenatal care of a woman with trauma due to an accident were poor. Competency in the antenatal care of battered pregnant women and pregnant women practising substance abuse was rated poor by $21,4 \%$ and $23,9 \%$ of the respondents respectively. Most of the respondents evaluated their competency as reasonable or good in the antenatal care of women with pathology. Only a few respondents indicated their competency on the antenatal care of women in this category as very good or excellent.

\section{- Self-perceived competency: Intrapartum related nursing care}

This item consists of two parts. Respondents were questioned firstly about their knowledge and skills regarding nursing actions related to intrapartum care and secondly on their competency in giving patients information and advice on specific topics. These responses are set out in Table 4.

A small percentage $(18,7 \%, 15,5 \%$ and $21 \%)$ of the respondents rated their competency on monitoring a patient on specific medication (Ipradol R, Magnesium sulphate $\mathrm{R}$ and Syntocinon $\mathrm{R}$ ) as very good or excellent.

Two hundred and eight-seven of the respondents $(55,8 \%)$ indicated that their competency in setting up a cardiotocograph monitor was poor, while an even larger percentage $59,5 \%$ evaluated their competency in analysing and interpreting cardiotocograph findings as poor. The majority of the respondents indicated that they were not competent at applying foetal scalp electrodes. Three hundred and eighty-two of the respondents $(74,3 \%)$ evaluated their competency in this skill as poor. A further $40,7 \%$ perceived themselves to be poorly competent in detecting threatening uterine rupture. These findings underline the poor competency respondents indicated in assessing foetal well-being and uterine activity in the antepartum period.

It is interesting to note that $19,2 \%$ of the respondents rated their competency (very good or excellent) higher in the treatment of foetal distress than in its diagnosis (analysing and interpreting cardiotocograph findings $12,9 \%$ ). However, competency in the treatment of uterine hyperactivity was perceived by $48,4 \%$ of the respondents as poor.

A large number of respondents $45,7 \%$ rated their competency in assisting the anaesthetist during the administration of an epidural anaesthetic as poor. What is even more alarming is that $55,8 \%$ of the respondents were poorly competent in recognising spinal shock - a life-threating complication of epidural anaesthesia. The administration of Entonox seems also to be a problem. Three hundred and thirty-seven of the respondents $(65,6 \%)$ evaluated their competency in this skill as poor.

It is not surprising that a very small percentage of the respondents rated their competency in assisted deliveries as very good or excellent, as these are viewed as advanced skills. Six percent and $6,8 \%$ of the respondents respectively indicated that they were very good or excellent at forceps and vacuum extraction deliveries, while $9,9 \%$ evaluated their competency in breech deliveries on the same level. Only $1,8 \%$ of the respondents indicated that they were very good or excellent at performing a symphysiotomy. Very good or excellent competency in another advanced skill, manual removal of the placenta, was also indicated by few respondents, $8,1 \%$. 
TABLE 6: Self-perceived competency: Newborn nursing care

\begin{tabular}{|c|c|c|c|c|c|c|c|c|c|c|}
\hline \multirow[t]{2}{*}{ NEWBORN NURSING CARE } & \multicolumn{2}{|c|}{ Poor } & \multicolumn{2}{|c|}{ Reasonable } & \multicolumn{2}{|c|}{ Good } & \multicolumn{2}{|c|}{ Very Good } & \multicolumn{2}{|c|}{ Excellent } \\
\hline & $\mathbf{f}$ & $\%$ & $\mathbf{f}$ & $\%$ & $\mathbf{f}$ & $\%$ & $\mathbf{f}$ & $\%$ & $\mathbf{f}$ & $\%$ \\
\hline Physical assessment & 6 & 12.3 & 108 & 21.0 & 203 & 39.5 & 100 & 19.5 & 40 & 7.8 \\
\hline Neurological assessment & 116 & 22.6 & 135 & 26.3 & 175 & 34.0 & 72 & 14.0 & 16 & 3.1 \\
\hline Identifying congenital abnormalities & 77 & 15.0 & 129 & 25.1 & 189 & 36.8 & 90 & 17.5 & 29 & 5.6 \\
\hline Diagnosis of asphyxia & 84 & 16.3 & 144 & 28.0 & 187 & 36.4 & 80 & 15.6 & 19 & 3.7 \\
\hline Resuscitation of the newborn & 143 & 27.8 & 144 & 28.0 & 147 & 28.6 & 63 & 12.3 & 17 & 3.3 \\
\hline Suctioning (nose, mouth and throat) & 59 & 11.5 & 96 & 18.7 & 199 & 38.7 & 100 & 19.5 & 60 & 11.7 \\
\hline Nasogastric: & & & & & & & & & & \\
\hline - $\quad$ intubation & 212 & 41.4 & 114 & 22.3 & 109 & 21.3 & 52 & 10.2 & 25 & 4.9 \\
\hline - $\quad$ feeding & 78 & 15.2 & 91 & 17.7 & 172 & 33.5 & 109 & 21.2 & 64 & 12.5 \\
\hline Setting up an intravenous scalp line & 249 & 48.4 & 105 & 20.4 & 83 & 16.1 & 48 & 9.3 & 29 & 5.6 \\
\hline Taking blood & 233 & 45.3 & 111 & 21.6 & 83 & 16.1 & 54 & 10.5 & 33 & 6.4 \\
\hline Nursing the: & & & & & & & & & & \\
\hline sick neonate & 153 & 29.8 & 132 & 25.7 & 148 & 28.8 & 53 & 10.3 & 28 & 5.4 \\
\hline - $\quad$ premature neonate & 142 & 27.6 & 138 & 26.8 & 146 & 28.4 & 56 & 10.9 & 32 & 6.2 \\
\hline - $\quad$ small for gestational age neonate & 156 & 30.4 & 129 & 25.1 & 151 & 29.4 & 51 & 9.9 & 27 & 5.3 \\
\hline - $\quad$ respiratory distressed neonate & 180 & 35.0 & 129 & 25.1 & 131 & 25.5 & 48 & 9.3 & 26 & 5.1 \\
\hline - $\quad$ neonate with jaundice & 133 & 25.9 & 114 & 22.2 & 164 & 31.9 & 60 & 11.7 & 43 & 8.4 \\
\hline - $\quad$ neonate with hyper/hypoglycaemia & 192 & 37.4 & 131 & 25.5 & 123 & 23.9 & 43 & 8.4 & 25 & 4.9 \\
\hline - $\quad$ neonate with hypothermia & 161 & 31.3 & 125 & 24.3 & 143 & 27.8 & 50 & 9.7 & 35 & 6.8 \\
\hline
\end{tabular}

A hundred and eighty-eight of the respondents $(36,6 \%)$ indicated that they were poorly competent at repairing perineal tears. Competency in scrubbing for a caesarean section was perceived by $47,9 \%$ of the respondents as poor.

Eighty-six $(16,7 \%)$ and $13,6 \%$ of the respondents respectively rated themselves as being very good or excellent at alternative methods of pain control and positioning during labour. Very good or excellent competency in patient education regarding bonding was indicated by $30,4 \%$ of the respondents. It is encouraging that nearly half of the respondents, $46,3 \%$, perceived their competency in patient education on breastfeeding as very good or excellent.

\section{- Self-perceived competency: Postnatal nursing care}

This item is divided into two parts. The first question requested respondents to evaluate their competency in nursing skills associated with the postnatal period and the second question requests responses regarding their competency in family planning matters. These responses are set out in Table 5.

The results indicate that generally speaking respondents perceived their competency in nursing skills associated with the postnatal period much higher than nursing skills associated with the intrapartum period. It is interesting that competency in identifying involution of the uterus was the nursing skill that most respondents, $29 \%$, rated poorly. Two hundred-and- five of the respondents $(39,9 \%)$ indicated their competency in assessing hydration status as very good or excellent. It is interesting that $33,3 \%$ of the respondents rated their competency on facilitating breast feeding as very good or excellent, while more that half of them $(56,6 \%)$ indicated the same level of competency in operating a breast pump. A hundred and twenty-five of the respondents $(24,3 \%)$ also perceived their competency in providing emotional and physical comfort measures as poor.

Two hundred and thirty-nine of the respondents $(46,5 \%)$ rated their competency in nursing a patient who had had an epidural anaesthetic on a very good or excellent level, while competency in identifying and treating patients with complications related to childbirth on these levels was much lower. A hundred and seventy-four $(33,9 \%)$ and $31,5 \%$ of the respondents respectively indicated that they were very good or excellent at identifying patients at risk of postpartum depression and identifying and treating postpartum haemorrhage. A hundred and fifty-two $(29,6 \%)$ and $23,2 \%$ of the respondents rated their competency in identifying and treating infection of the genital tract and identifying and treating thrombosis as very good or excellent.

\section{- Self-perceived competency: Family planning care}

The respondents were requested to evaluate their competency regarding family planning. They indicated that they were fairly 
competent in the items listed under this question except for the insertion or removal of an intra-uterine contraceptive device. Two hundred and ninety-six of the respondents (57\%) rated their competency in these skills as poor, while only $11,1 \%$ indicated they were very good or excellent at inserting or removing an intrauterine contraceptive device.

\section{- Self-perceived competency: Newborn nursing care}

Two questions were asked under this item. Respondents were asked how well they assessed the newborn physically and neurologically, and they were requested to evaluate their competency in nursing actions related to neonatal care. The responses of the respondents are set out in Table 6 .

Only $27,2 \%$ of the respondents rated their competency in assessing the newborn physically as very good or excellent. Even a smaller percentage $17,1 \%$, indicated that they were very good or excellent at the neurological assessment of the newborn.

It is alarming to note that only $19,3 \%$ of the respondents indicated that they were very good or excellent at diagnosing asphyxia, while even fewer, only $15,6 \%$ of respondents believed they were very good or excellent at resuscitation of the newborn. Two hundred and forty-nine of the respondents $(48,4 \%)$ evaluated their competency in setting up an intravenous scalp line as poor. Taking blood from the newborn also seemed to be a problem, as $45,3 \%$ of the respondents indicated that their competency in this skill was poor.

Only $15,1 \%$ of the respondents indicated that they were very good or excellent at nasogastric intubation of the newborn, while $33,7 \%$ rated their competency in nasogastric feeding of the newborn on the same level.

A hundred and three of the respondents $(20,1 \%)$ indicated that they were very good or excellent at nursing the neonate with jaundice, while fewer than $18 \%$ believed they were very good or excellent at nursing the neonate with problems. One hundred and eighty of the respondents $(35 \%)$ evaluated their competency in nursing the respiratory distressed neonate as poor. Competency in nursing the neonate with hyper- or hypoglycaemia was rated by $37,4 \%$ of the respondents as poor.

\section{Discussion}

Some of the respondents made comments at the end of the questionnaire. They remarked that they had lost their competency in a number of midwifery related skills, because they had not updated these after completion of their basic midwifery training. They felt that continuing education programmes in midwifery are necessary, as they feel particularly concerned about their competency in this field after completion of the questionnaire. Continuing education programmes in other fields of nursing were also suggested.

It is striking that respondents $(57,6 \%)$ who indicated that they were currently providing midwifery services or had provided midwifery services as a registered nurse the past one to two years, rated their overall competency much higher than the other respondents. The chi-square and Fisher's exact test used to determine whether a significant difference exists, were equal or lower than 0,05 in most of the questions in Checklist B.

No statistically significant difference in competency was noted between respondents who indicated that they were currently providing midwifery services or had provided midwifery services as a registered nurse the past one to two years and respondents who indicated that they had not provided midwifery services as a registered nurse for the past three of more years, in nursing care such as setting up an infusion pump, adult resuscitation, administering oxygen, wound care, identifying psychological needs, conducting research, writing a research report, interpreting research findings, training community health workers, recognising spinal shock and taking blood from a neonate. All of these skills except for taking blood from a neonate are considered general nursing skills.

The information obtained through the questionnaire underlines the importance of needs assessment in the development of an educational programme. Advanced midwifery educational programmes emphasize the teaching of advanced midwifery knowledge and skills and accept that the students entering these programmes already have specific knowledge and skills included in the curricula for basic courses.

This is contrary to the findings of this study. Competency in knowledge and skills associated with basic courses, for example adult resuscitation, South African Nursing Council regulations, assessing foetal well-being, and identifying involution of the uterus and perineum to name a few, were alarmingly low. On the other hand, competency in knowledge and skills such as operating a breast pump and nursing a patient who has had an epidural anaesthetic were rated much higher than expected.

These findings could be due to the fact that $81,6 \%$ of the respondents completed their basic training more that 10 years ago, that $71 \%$ of them are not furthering their education and that primary health care has not been strongly emphasized until recently. The competencies which were rated higher than expected, as previously mentioned, may be due to the fact that $55,5 \%$ of the respondents are hospital based and these skills are usually associated with nursing care practised in hospitals.

The data indicates that respondents do not have specific knowldge and skills needed for entering an advanced educational programme.

\section{Recommendations and conclusion}

If at the outset the educational needs of students or those of the society from which they come are not understood, they might be wrongly addressed (Matiru et al., 1995:40). The summary of training needs should therefore establish the main areas and priorities for training (Bandaranayake \& Irvine, 1985:11).

By doing this, the curriculum planner will ensure that the needs and interests of the learners are being met, thus creating an appropriate educational programme. It is just as important when preparing lectures or seminars as when design- 
ing an entire programme, and will provide essential guidelindes for determining content, or the educational strategies to be adopted in an educational programme (Laidlaw et al., 1995:87).

It is therefore part of the first step in the development of an education programme and can also be used to identify relevant problems, such as when students lack specific knowledge and skills included in the curricula for basic programmes, and to focus on areas of maximum benefit to individual students, lecturers, the community and in the long run, the university as a whole (Matiru et al., 1995:40).

It is considered a critical part of a systematic approach to developing educational projects and ensures relevancy which is arguably the most important criterion of effective education. This is particularly important when time for educational activities is at a premium and when these activities have to be cost effective.

\section{References}

BANDARANAYAKE RC \& IRVINE SS 1985: Designing appropriate training programmes. Sydney: The University of New South Wales.

BURNS N \& GROVE SK 1997: The practice of nursing research, conduct, critique and utilization. Philadelphia: W.B. Saunders Company.

DIAMOND MR 1989: Designing and improving courses and curricula in higher education. San Francisco: Josey-Bass Inc.

LAIDLAW JM; HARDEN RM \& MORRIS A 1995: Needs assessment and the development of an educational programme on malignant melanoma for general practitioners. Medical Teacher, 17(1):79-87.

LO BIONDO-WOOD G \& HABER J 1990: Nursing research, methods, critical appraisal and utilization. 2nd ed. St. Louis: The C.V. Mosby Company.

MATIRU B; MWANGI A \& SCHLETTE R 1995: Teach your best: A handbook for university lecturers. Bonn: German Foundation for International Development.

MURRAY LM 1982: A comparison of lecture discussion and self-study methods in nursing education. Journal of Nursing Education, 21(9):17-23. 